\title{
PHYSIOLOGICAL RESPONSE, SEMEN QUALITY AND BLOOD BIOCHEMICAL PARAMETERS OF RABBIT BUCKS SUPPLEMENTED WITH PHYTOGENIC COMPONENTS DURING SUMMER SEASON OF EGYPT
}

\author{
A. S. Abdel-Azeem ${ }^{1}$, Amal M. A. Fayed ${ }^{2}$ and A. A. Azoz ${ }^{2}$ \\ ${ }^{1}$ Poultry Department, Faculty of Agriculture, Fayoum University, Fayoum, Egypt. \\ ${ }^{2}$ Animal Production Research Institute, Agricultural Research Center, Dokki, Giza, Egypt. \\ Corresponding author: Abdel-Azeem, A. S., Email: asa10@fayoum.edu.eg
}

(Received 1/11/2018, accepted 18/12/2018)

\section{SUMMARY}

$\mathrm{S}$ eventy-two mature New Zealand White (NZW) rabbit's bucks were randomly and equally divided into eight groups each of nine bucks to evaluate the impact each of rocket seeds (RS), carrot seeds (CS), or bay laurel leaves (BLL) and their mixtures on semen quality, biochemical components and the physiological response of NZW rabbits bucks during hot summer conditions. The study started in June and lasted for 8 weeks. Eight experimental diets were formulated such that diet (D1) free additives as a control group. Diets 2, 3 and 4 contained 1.0\% RS, $1.0 \% \mathrm{CS}$ and 1.0\% BLL, respectively. Diet 5, 6 and 7 contained a mix of $0.5 \%$ $\mathrm{RS}+0.5 \% \mathrm{CS}, 0.5 \% \mathrm{CS}+0.5 \% \mathrm{BLL}$ and $0.5 \% \mathrm{RS}+0.5 \% \mathrm{BLL}$, respectively, while diet 8 contained $0.33 \%$ $\mathrm{RS}+0.33 \% \mathrm{CS}+0.33 \%$ BLL. Insignificant effect on buck's body weight, however, feed intake was significantly increased as compared to bucks group given the control diet. Supplementation with RS, CS, BLL, and their mixtures caused significant improvement in ejaculate volume, individual motility, total motile sperm, sperm concentration, live sperm\%, total functional sperm fraction, total sperm output, and decreased abnormal sperm\%. Seminal plasma initial fructose and globulin increased significantly with RS, CS, BLL, and their mixtures treatments. Seminal plasma alkaline phosphatase (ALP), alanine aminotransferase (ALT), and aspartate aminotransferase (AST) appeared reduction significantly with the RS, CS, BLL and their mixtures treatments. Seminal plasma total antioxidant capacity (TAC) increased, while, malondialdehyde (MDA) levels significantly decreased in all supplemented groups compared with the control bucks' value. Most of the supplemented groups showed a significant decrease in blood plasma glucose, cholesterol, triglycerides, and total lipids, low-density lipoproteins, AST and ALT as compared to the control group. However, blood plasma total protein and albumin were increased in comparison with the control group. Blood plasma TAC significantly increased due to the addition of RS, CS, BLL, and their mixtures as compared to the control group, but MDA levels decreased.

Keyword: Semen, Rocket, Carrot, Bay laurel, Heat Stress, Total Antioxidant Capacity, Malondialdehyde.

\section{INTRODUCTION}

In Egypt, summer temperature increases to more than $40 \mathrm{C}^{\circ}$. Some villagers believe that domestic rabbits as wild rabbit living outside can withstand extreme climatic conditions. This, in fact, is not as true as it occurs. Rabbits exhibit an inability to dissolve sufficient heat to maintain homeothermy. In addition, the relative humidity and metabolic heat are also, causative of heat stress. Most small - scale rabbit producers in the Egyptian villages confront numerous challenges, particularly stress of heat, related to the hot climate, that had a significant adverse effect on reproductive performance (Elnagar, 2010) and produces enormous economic losses (Ondruska et al. 2011, Mahrose et al., 2010), cause a rise in oxidative stress (Lee, 2002) that may obstruct resistance to disease and weaken the status of antioxidants (Sabin et al., 2001).

Recently, it was shown that in rabbit's fed natural feed additives (rocket seeds, carrot seeds or bay laurel leaves and their mixture) have increased antioxidant activities of rabbit females (Basyony and Azoz, 2017). 


\section{Abdel-Azeem et al.}

There is a growing interest in using natural sources of plants with medicinal properties, rocket (Eruca sativa) in Egypt. The strong demand for volatile oils for pharmaceutical goals has been steadily increasing. This plant has been found to personify the body condition to reduce disease stress (Eisenberg et al., 1993).

Rocket seeds comprise vitamin C, flavonoids (luteoline and appiine), glucosinolates the ancestors of sulfaraphene and isothiocyanates, and carotenoids (Talalay and Fahey, 2001), volatile oils such as apiole $\beta$ phellandrene, myristicin (Leung and Foster, 1996, Bradley, 1992).

Glucosinolates have been found, which contain numerous antioxidant, antibacterial, anticarcinogenic and antifungal biological efficacy (Kim et al., 2004). Additionally, have $\mathrm{Fe}, \mathrm{Mn}, \mathrm{Cu}, \mathrm{Mg}, \mathrm{Zn}$ and further elements (Abdo, 2003), that rise immune response of addition rocket seed, in rabbit fed diets significantly improved daily body gain and feed conversion and decrease daily feed intake (El-Nomeary et al., 2016).

Carrot plants (Daucus Carota L) also contain a unique mixture of three flavonoids; quercetin, luteolin, and kaempferol (Horbowicz, et al., 2008, Ching and Mohamed, 2001). Furthermore, they are opulent in other phenols along with several derivatives of cinnamic acid, containing $\beta$-hydroxybenzoic acids, caffeic and chlorogenic. Seeds of carrot caused to decrease in cholesterol (Da Silva Dias, 2014). Muralidharan et al., (2008) observed that in carrot seed extract fed rats; levels of plasma lactate dehydrogenase, alanine transaminase, and aspartate transaminase were significantly declined. Moreover, Singh et al. (2010) observed that rats fed with carrot seeds showed a significant increase in antioxidant enzyme levels such as glutathione peroxidase, superoxide dismutase and, catalase as compared with the control group of rats.

Also, Bay laurel Nobilis L, which was presented as the high level of nutritional support due to the content of organic acids, polyunsaturated fatty acids, tocopherols and free sugars together with activity of antioxidant, like lipid peroxidation inhibition, scavenging effectiveness, and plummeting power (Dias et al. 2014). Plasma thiobarbituric acid reactive substances level was statistically lower in the rabbits receiving bay leaves in their diets, but plasma total antioxidant capacity was higher (Casamassima et al., 2016).

The purpose of this investigation was hence to study the physiological response (body weight and feed intake), semen quality, antioxidant activities and blood biochemical parameters of rabbit bucks fed natural feed additives as rocket (Eruca Sativa) seeds, carrot seeds or Bay laurel leaves and their mixture during the hot climate periods.

\section{MATERIAL AND METHODS}

The experimental action was conducted at the Animal Production Research Station, El Nobaria (Behara Governorate), Animal Production Research Institute, Agricultural Research Center, Agriculture Ministry, Egypt. It was started in June and lasted for 8 weeks.

\section{Experimental design}

A total of 72 adults buck rabbits from New Zealand White (NZW) at age 7 months (mean initial body weight, $3095 \mathrm{~g}$ ) were randomly assigned to eight experimental treatment groups each of nine bucks and assigned to a 2 X 4 factorial arrangement in a Completely Randomized Design. The buck rabbits were fed a diet in according to the following treatments order:

D1: Basal diets as a control group.

$\mathrm{D} 2:+1.0 \%$ rocket seeds.

D3: $+1.0 \%$ carrot seeds.

D4: $+1.0 \%$ bay laurel leaves.

D5: $+0.5 \%$ rocket seeds $+0.5 \%$ carrot seed.

D6: $+0.5 \%$ carrot seeds $+0.5 \%$ bay laurel leaves.

D7: $+0.5 \%$ rocket seeds $+0.50 \%$ bay laurel leaves.

D8: $+0.33 \%$ rocket seeds $+0.33 \%$ carrot seeds $+0.33 \%$ bay laurel leaves.

\section{Experimental diets and housing}

Rabbits were kept separately in galvanized wire cages (dimensions: $30 / 20 / 35 \mathrm{~cm}$ ) under a light-dark cycle of 16:8 h. Pelleted feed ad libitum was fed to all rabbits. The experimental diet's chemical structure and feed ingredients are displayed in Table (1). Isocaloric and isonitrogenic were experimental diets. The experimental diets have been prepared to match to Lebas (2004) to converge the recommended nutrient 
requirements of buck rabbits. A crushing machine (Thomas Wiley laboratory mill, model \# 4, screen size-1 $\mathrm{mm}$ ) was crushed in the laboratory plant seed material. Display to sunlight was averted to inhibit the damage of active constituents. Rocket seeds, carrot seeds, and bay laurel leaves with different levels as shown previous were mingled with one $\mathrm{kg}$ of every diet and mingled in the residual diet to achieve a homogeneous level of inclusion. Whole rabbits were retained in the same management, hygienic and environmental conditions. Rabbits were reared in a well-ventilated building; fresh water was automatically available all the time by stainless steel nipples fixed in each cage. During the experimental period (June-August), in the rabbitry, the minimum and maximum temperatures, the relative humidity, and the temperature-humidity index ranged $26.5-33.5^{\circ} \mathrm{C}, 62-75 \%$ and $87.5-93.5$, respectively. That means, during the whole experimental period rabbits were under harsh stress of heat as LPHSI (1990) describes.

Table (1). Composition and calculated chemical analyses (\%) of the experimental diets.

\begin{tabular}{|c|c|c|c|c|c|c|c|c|}
\hline Ingredient & D1 & D2 & D3 & D4 & D5 & D6 & D7 & D8 \\
\hline Dried Egyptian clover & 30.20 & 29.93 & 29.85 & 29.60 & 29.93 & 29.85 & 29.60 & 29.91 \\
\hline Barley & 20.00 & 19.00 & 19.00 & 19.00 & 19.00 & 19.00 & 19.00 & 19.00 \\
\hline Rocket seed & 0.00 & 1.00 & 0.00 & 0.00 & 0.50 & 0.00 & 0.50 & 0.33 \\
\hline Carrot seed & 0.00 & 0.00 & 1.00 & 0.00 & 0.50 & 0.50 & 0.00 & 0.33 \\
\hline Bay laurel leaf & 0.00 & 0.00 & 0.00 & 1.00 & 0.00 & 0.50 & 0.50 & 0.33 \\
\hline Yellow corn & 14.80 & 15.00 & 15.00 & 15.00 & 15.00 & 15.00 & 15.00 & 15.00 \\
\hline Wheat bran & 10.00 & 10.00 & 10.00 & 10.00 & 10.00 & 10.00 & 10.00 & 10.00 \\
\hline Soybean meal ( $44 \% \mathrm{CP})$ & 19.60 & 19.67 & 19.75 & 20.00 & 19.67 & 19.75 & 20.00 & 19.70 \\
\hline Molasses & 3.00 & 3.00 & 3.00 & 3.00 & 3.00 & 3.00 & 3.00 & 3.00 \\
\hline Limestone & 1.00 & 1.00 & 1.00 & 1.00 & 1.00 & 1.00 & 1.00 & 1.00 \\
\hline Di-Calcium phosphate & 0.30 & 0.30 & 0.30 & 0.30 & 0.30 & 0.30 & 0.30 & 0.30 \\
\hline Sodium chloride & 0.50 & 0.50 & 0.50 & 0.50 & 0.50 & 0.50 & 0.50 & 0.50 \\
\hline Vit-Min premix ${ }^{*}$ & 0.30 & 0.30 & 0.30 & 0.30 & 0.30 & 0.30 & 0.30 & 0.30 \\
\hline L-Lysine & 0.15 & 0.15 & 0.15 & 0.15 & 0.15 & 0.15 & 0.15 & 0.15 \\
\hline Methionine & 0.15 & 0.15 & 0.15 & 0.15 & 0.15 & 0.15 & 0.15 & 0.15 \\
\hline Total & 100 & 100 & 100 & 100 & 100 & 100 & 100 & 100 \\
\hline \multicolumn{9}{|c|}{ Calculated chemical analysis (\%, according to NRC, 1977) } \\
\hline Dry matter & 89.19 & 89.11 & 89.21 & 89.13 & 89.12 & 89.16 & 89.13 & 89.49 \\
\hline Organic matter & 82.56 & 82.36 & 82.54 & 82.36 & 82.43 & 82.45 & 82.38 & 82.54 \\
\hline Crude protein & 16.2 & 16.18 & 16.17 & 16.11 & 16.17 & 16.16 & 16.10 & 16.01 \\
\hline Crude fiber & 12.34 & 12.39 & 12.41 & 12.51 & 12.40 & 12.80 & 12.11 & 12.69 \\
\hline Ether Extract & 2.60 & 2.62 & 2.62 & 2.63 & 2.61 & 2.61 & 2.63 & 2.61 \\
\hline Ash & 6.63 & 6.75 & 6.67 & 6.77 & 6.69 & 6.71 & 6.75 & 6.95 \\
\hline $\mathrm{NFE}^{* *}$ & 51.42 & 51.17 & 51.34 & 51.11 & 51.25 & 50.88 & 51.54 & 51.23 \\
\hline $\mathrm{NDF} * * *$ & 37.03 & 37.06 & 37.07 & 37.14 & 37.07 & 37.33 & 36.89 & 37.26 \\
\hline $\mathrm{DE}(\mathrm{kcal} / \mathrm{kg}) * * * *$ & 2542.0 & 2540.3 & 2539.70 & 2536.5 & 2540.0 & 2527.1 & 2549.4 & 2530.7 \\
\hline
\end{tabular}

* Vit. and Min. mixture: Each kilogram of Vit. and Min. mixture contains: 150.000 IU Vit. D, 2000.000 IU Vit. A, $8.33 \mathrm{~g}$ Vit. E, $0.33 \mathrm{~g}$ Vit. B1, $0.33 \mathrm{~g}$ Vit. K, $1.0 \mathrm{~g}$ Vit. B2, $0.33 \mathrm{~g}$ Vit. B6, $1.7 \mathrm{mg}$ Vit. B 1, $8.33 \mathrm{~g}$ Vit.B 5, $23.33 \mathrm{~g}$ Pantothenic acid, $33 \mathrm{mg}$ Biotin, 0.83g Folic acid, $11.7 \mathrm{~g} \mathrm{Zn,} 12.5 \mathrm{~g}$ Fe, $16.6 \mathrm{mg}$ Co, $66.7 \mathrm{~g} \mathrm{Mg} 16.6 \mathrm{mg} \mathrm{Se,} 5 \mathrm{~g} \mathrm{Mn}$., I 0.2mg and $200 \mathrm{~g}$ Choline chloride $* * N F E=$ Nitrogen free extract $; * * N D F=$ Neutral detergent fibre; $* * * D E=$ Digestible energy of the experimental diets was calculated according to the equation described by Cheeke et al. (1986) as follows: $D E(\mathrm{kcal} / \mathrm{g})=4.36-$ $0.0491 X N D F \%, N D F=28.924+0.657 \times C F \% ; D 1=$ free additives supplementations $(C), D 2=C+1.0 \%$ rocket seeds, $D 3=C+$ $1.0 \%$ carrot seeds, $D 4=C+1.0 \%$ bay laurel leaves, $D 5=C+0.5 \%$ rocket seeds $+0.5 \%$ carrot seeds, $D 6=C+0.5 \%$ carrot seeds $+0.5 \%$ bay laurel leaves, $D 7=C+0.5 \%$ rocket seeds $+0.50 \%$ bay laurel leaves, $D 8=C S+0.33 \%$ rocket seeds $+0.33 \%$ carrot seeds $+0.33 \%$ bay laurel leaves.

\section{Collection of data}

For the whole experimental duration, feed intake and body weight were gauged. Utilizing an artificial vagina, semen samples were gathered weekly from each buck and chemical analysis of the samples was performed each week. Semen collection and handling were carried out and evaluated according to the international guidelines of (IRRG, 2005). Ejaculated volume was gauged to the nearest $0.01 \mathrm{~mL}$. Weak eosin-formalin (10\% formalin) solution was used for evaluation of sperm concentration by the improved 
Neubauer hemocytometer slide method as described by Perumal et al. (2017). Total sperm output (TSO, $10 \%$ ejaculate) was calculated by multiplying semen ejaculate volume (mL) by sperm concentration $\left(10^{6} / \mathrm{mL}\right)$. Individual sperm motility was estimated at 400× magnification (Srivastava and Pande 2017a). Total motile sperm count (TMSC, $10^{6}$ /ejaculate), which is obtained by multiplying the sperm concentration $(10 \% \mathrm{~mL})$, the ejaculate volume $(\mathrm{mL})$ and the percentage of individual motility. Total functional sperm fraction (TFSF, $10 \%$ ejaculate) as a product of TMSC by percentage of normal sperm morphology.

Seminal initial fructose assessment was conducted immediately after collection (Srivastava and Pande, 2017b). An eosin - aniline blue staining mixture was used to evaluate abnormal spermatozoa (Srivastava et al., 2017). Seminal plasma was seceded for 20 minutes by centrifugation at $3000 \mathrm{rpm}$ and stowed at -20 Co in Eppendorf tubes. Total protein, albumin, total lipids, cholesterol, total antioxidant capacity, malondialdehyde, alkaline phosphatase (ALP), ALT and AST were calorimetrically determined in seminal plasma using commercial kits obtained from (BIO- DIAGNOSTICS, Egypt) in accordance with the procedure outlined by the manufacturer.

Plasma was obtained by blood samples centrifugation for $20 \mathrm{~min}$ at $4000 \mathrm{rpm}$ and stored at $-20^{\circ} \mathrm{C}$ in Eppendorf tubes until analysis. According to Fringes et al. (1972), Doumas et al. (1977), Armstrong and Carr (1964), respectively, the blood plasma total lipids, triglycerides, and glucose, were gauged using the spectrophotometer.

According to Johnson et al. (1999), albumin and total protein were measured; subtracting albumin values from the corresponding total protein values also obtained globulin values. Total cholesterol, lipoproteins of low density (LDL) and lipoproteins of high density (HDL) have been identified according to Burstein et al. (1970), Wieland and Seidel (1983), Bogin and Keller (1987), also very lowdensity lipoproteins (vLDL) was calculated as one-fifth of triglycerides. Plasma urea, AST and ALT were assayed according to Fawcett and Scott (1960), Reitman and Frankel (1975), respectively. Plasma total capacity of antioxidant (TAC) and lipid peroxidation; malondialdehyde (MDA) were gauged using Koracevic et al. (2001) method by calorimetric.

\section{Statistical analysis}

The experiment data were analyzed using one-way ANOVA from the SAS ® GLM procedure (SAS Institute, 2000), using the following model: $y_{i j}=\mu+T_{i}+e_{i j}$, Where: $\mu=$ Overall mean $y_{i j}, T=$ treatment effect) and $\mathrm{e}_{\mathrm{ij}}=$ experimental error. Using Duncan multi-range test (Duncan, 1955), the significant differences between means were detected.

\section{RESULTS AND DISCUSSION}

\section{Effect of phytogenic feed additives on the physiological response (body weight and feed intake)}

Dietary supplementation with different feed additives caused an insignificant effect on body weight of bucks, however, feed intake was significantly $(\mathrm{P} \leq 0.05)$ increased compared with the group of bucks given the control diet (Table 2).

Table (2): Overall means ( \pm SE) of body weight and feed intake of rabbit bucks fed diets containing rocket seeds, carrot seeds, bay laurel leaves powder and their mixture during the experimental periods.

\begin{tabular}{lrc}
\hline Treatment & $\begin{array}{c}\text { Body weight } \\
(\mathrm{g})\end{array}$ & $\begin{array}{c}\text { Feed intake } \\
(\mathrm{g} / \mathrm{kg} / \mathrm{day})^{*}\end{array}$ \\
\hline Free additives supplementations (control, C), D1 & $3037 \pm 0.02$ & $40.90 \pm 0.52^{b}$ \\
C $+1.0 \%$ rocket seeds (D2) & $3090 \pm 0.05$ & $42.80 \pm 0.54^{\mathrm{a}}$ \\
$\mathrm{C}+1.0 \%$ carrot seeds (D3) & $3120 \pm 0.04$ & $43.20 \pm 0.66^{\mathrm{a}}$ \\
$\mathrm{C}+1.0 \%$ bay laurel leaves (D4) & $3070 \pm 0.04$ & $42.50 \pm 0.45^{\mathrm{a}}$ \\
$\mathrm{C}+0.5 \%$ rocket seeds+0.5\% carrot seeds (D5) & $3045 \pm 0.04$ & $43.00 \pm 0.53^{\mathrm{a}}$ \\
$\mathrm{C}+0.5 \%$ carrot seeds+0.5\% bay laurel leaves (D6) & $3080 \pm 0.04$ & $42.80 \pm 0.50^{\mathrm{a}}$ \\
$\mathrm{C}+0.5 \%$ rocket seeds+0.50\% bay laurel leaves (D7) & $3060 \pm 0.05$ & $42.90 \pm 0.53^{\mathrm{a}}$ \\
$\mathrm{C}+0.33 \%$ rocket seeds+0.33\% carrot seeds+0.33\% bay laurel leaves (D8) & $3050 \pm 0.04$ & $42.70 \pm 0.63^{\mathrm{a}}$ \\
\hline${ }^{a, b}$ Means within a column having different superscripts are significantly different $(P \leq 0.05)$. & \\
${ }^{*}$ (g /kg/ day) = g for each 1 Kg of body weight in the day. & &
\end{tabular}


Our results of feed intake were agreed with Ibrahim (2005), who found the basal diet supplemented by $1 \%$ rocket seed caused increase the feed intake when compared with the control group. The increase in feed intake of all groups treated compared to the control group this may be due to the stimulating effect of rocket seeds, carrot seeds or bay laurel leaves on the gastrointestinal system by enhancing dietary palatability and appetite.

\section{Effect of phytogenic feed additives on Semen quality}

Table (3) shows the overall means of ejaculate volume, individual motility, and sperm concentration. Ejaculate volume, individual motility and sperm concentration of rabbit bucks showed higher in D2, D5, D7, and D8 groups than D1, D3, D4, and D6 groups.

Table (3): Overall means $( \pm \mathrm{SE})$ of semen ejaculate volume, individual motility and sperm concentration of rabbit bucks fed diets containing rocket seeds, carrot seeds, bay laurel leaves powder and their mixture during the experimental periods.

\begin{tabular}{lccc}
\hline Treatment & $\begin{array}{c}\text { Ejaculate } \\
\text { volume } \\
(\mathrm{ml})\end{array}$ & $\begin{array}{c}\text { Individual } \\
\text { motility } \\
(\%)\end{array}$ & $\begin{array}{c}\text { Sperm } \\
\text { concentration } \\
\left(\times 10^{6} / \mathrm{ml}\right)\end{array}$ \\
\hline Free additives supplementations (control, C), D1 & $0.66 \pm 0.02^{\mathrm{c}}$ & $68.30 \pm 0.71^{\mathrm{c}}$ & $242.50 \pm 4.97^{\mathrm{c}}$ \\
C $+1.0 \%$ rocket seeds (D2) & $0.91 \pm 0.03^{\mathrm{a}}$ & $84.10 \pm 0.91^{\mathrm{a}}$ & $269.10 \pm 3.97^{\mathrm{a}}$ \\
C + 1.0\% carrot seeds (D3) & $0.68 \pm 0.02^{\mathrm{c}}$ & $66.90 \pm 0.73^{\mathrm{c}}$ & $233.00 \pm 4.54^{\mathrm{c}}$ \\
C + 1.0\% bay laurel leaves (D4) & $0.70 \pm 0.02^{\mathrm{c}}$ & $67.90 \pm 1.26^{\mathrm{c}}$ & $241.30 \pm 3.30^{\mathrm{c}}$ \\
C + 0.5\% rocket seeds+0.5\% carrot seeds (D5) & $0.89 \pm 0.02^{\mathrm{b}}$ & $81.40 \pm 1.10^{\mathrm{ab}}$ & $262.90 \pm 3.34^{\mathrm{a}}$ \\
C + 0.5\% carrot seeds+0.5\% bay laurel leaves (D6) & $0.70 \pm 0.02^{\mathrm{c}}$ & $67.10 \pm 1.20^{\mathrm{c}}$ & $237.80 \pm 3.71^{\mathrm{c}}$ \\
C + 0.5\% rocket seeds+0.50\% bay laurel leaves (D7) & $0.88 \pm 0.02^{\mathrm{b}}$ & $80.40 \pm 0.80^{\mathrm{ab}}$ & $259.30 \pm 3.24^{\mathrm{a}}$ \\
C + 0.33\% rocket seeds+0.33\% carrot seeds+0.33\% bay & $0.81 \pm 0.02^{\mathrm{b}}$ & $78.40 \pm 0.85^{\mathrm{b}}$ & $251.10 \pm 3.14^{\mathrm{b}}$ \\
laurel leaves (D8) & & &
\end{tabular}

Table (4) showed that D2, D5 and D7 treatment groups significantly $(\mathrm{P} \leq 0.05)$ increased in total motile sperm, total sperm output, and total functional sperm fraction due to different supplementations of feed additives as compared with the rest of treatment and control groups.

Table (4): Overall means ( \pm SE) of total sperm output, total motile sperm and total functional sperm fraction of rabbit bucks fed diets containing rocket seeds, carrot seeds, bay laurel leaves powder and their mixture during the experimental periods.

\begin{tabular}{lccc}
\hline Treatment & $\begin{array}{c}\text { Total sperm } \\
\text { output } \\
\left(\times 10^{6}\right)\end{array}$ & $\begin{array}{c}\text { Total motile } \\
\text { sperm count } \\
\left(\times 10^{6}\right)\end{array}$ & $\begin{array}{c}\text { Total functional } \\
\text { sperm fraction } \\
\left(\times 10^{6}\right)\end{array}$ \\
\hline Free additives supplementations (control, C) ,D1 & $160.05 \pm 6.77^{\mathrm{c}}$ & $109.31 \pm 3.99^{\mathrm{d}}$ & $90.84 \pm 3.47^{\mathrm{c}}$ \\
$\mathrm{C}+1.0 \%$ rocket seeds (D2) & $244.88 \pm 4.95^{\mathrm{a}}$ & $205.94 \pm 9.68^{\mathrm{a}}$ & $182.70 \pm 9.06^{\mathrm{a}}$ \\
$\mathrm{C}+1.0 \%$ carrot seeds (D3) & $158.44 \pm 7.68^{\mathrm{c}}$ & $105.99 \pm 6.04^{\mathrm{d}}$ & $87.98 \pm 5.58^{\mathrm{c}}$ \\
$\mathrm{C}+1.0 \%$ bay laurel leaves (D4) & $168.91 \pm 6.67^{\mathrm{c}}$ & $114.68 \pm 7.48^{\mathrm{c}}$ & $95.65 \pm 7.20^{\mathrm{c}}$ \\
$\mathrm{C}+0.5 \%$ rocket seeds+0.5\% carrot seeds (D5) & $233.98 \pm 6.15^{\mathrm{a}}$ & $190.46 \pm 7.60^{\mathrm{a}}$ & $168.56 \pm 7.24^{\mathrm{a}}$ \\
$\mathrm{C}+0.5 \%$ carrot seeds+0.5\% bay laurel leaves (D6) & $166.46 \pm 7.01^{\mathrm{c}}$ & $111.69 \pm 7.60^{\mathrm{c}}$ & $93.27 \pm 7.24^{\mathrm{c}}$ \\
$\mathrm{C}+0.5 \%$ rocket seeds+0.50\% bay laurel leaves (D7) & $228.18 \pm 7.35^{\mathrm{a}}$ & $183.46 \pm 7.60^{\mathrm{a}}$ & $158.69 \pm 7.24^{\mathrm{a}}$ \\
$\mathrm{C}+0.33 \%$ rocket seeds+0.33\% carrot seeds+0.33\% & & & \\
bay laurel leaves (D8) & $203.39 \pm 7.22^{\mathrm{b}}$ & $159.45 \pm 7.60^{\mathrm{b}}$ & $139.53 \pm 7.24^{\mathrm{b}}$ \\
\hline a,b,c,d Means within a column having different superscripts are significantly different $(P \leq 0.05)$. &
\end{tabular}

The results illustrated in Table (5) indicated that administration of (rocket seeds, carrot seeds, and bay laurel leaves) with different levels diet significantly $(\mathrm{P} \leq 0.05)$ raised initial fructose, conversely, they had significant decrease influence on abnormal sperm $\%$ as compared to the monitoring group. Additionally, significant $(\mathrm{P} \leq 0.05)$ improvement in live sperm \% as compared to the control group. 
Table (5): Overall means ( \pm SE) of live sperm, abnormal sperm and initial fructose concentration of rabbit bucks fed diets containing rocket seeds, carrot seeds and their mixture and bay laurel leaves powder during the experimental periods.

\begin{tabular}{|c|c|c|c|}
\hline Treatment & $\begin{array}{l}\text { Live sperm } \\
(\%)\end{array}$ & $\begin{array}{l}\text { Abnormal } \\
\text { sperm }(\%)\end{array}$ & $\begin{array}{l}\text { Initial fructose } \\
(\mathrm{Mg} / 100 \mathrm{ml})\end{array}$ \\
\hline Free additives supplementations (control, C), D1 & $71.00 \pm 0.41^{\mathrm{c}}$ & $16.90 \pm 0.38^{\mathrm{a}}$ & $235.60 \pm 5.27^{b}$ \\
\hline $\mathrm{C}+1.0 \%$ rocket seeds $(\mathrm{D} 2)$ & $80.30 \pm 0.55^{\mathrm{a}}$ & $11.30 \pm 0.46^{\mathrm{c}}$ & $287.20 \pm 7.53^{\mathrm{a}}$ \\
\hline $\mathrm{C}+1.0 \%$ carrot seeds $(\mathrm{D} 3)$ & $75.10 \pm 0.42^{\mathrm{b}}$ & $17.00 \pm 0.31^{\mathrm{a}}$ & $285.90 \pm 7.88^{\mathrm{a}}$ \\
\hline $\mathrm{C}+1.0 \%$ bay laurel leaves (D4) & $76.80 \pm 0.60^{\mathrm{b}}$ & $16.60 \pm 0.52^{\mathrm{a}}$ & $291.10 \pm 10.54^{\mathrm{a}}$ \\
\hline $\mathrm{C}+0.5 \%$ rocket seeds $+0.5 \%$ carrot seeds (D5) & $79.80 \pm 0.61^{\mathrm{a}}$ & $11.50 \pm 0.41^{\mathrm{c}}$ & $292.00 \pm 6.19^{\mathrm{a}}$ \\
\hline $\mathrm{C}+0.5 \%$ carrot seeds $+0.5 \%$ bay laurel leaves (D6) & $74.80 \pm 0.56^{\mathrm{b}}$ & $16.50 \pm 0.41^{\mathrm{a}}$ & $297.00 \pm 6.12^{\mathrm{a}}$ \\
\hline $\mathrm{C}+0.5 \%$ rocket seeds $+0.50 \%$ bay laurel leaves (D7) & $78.10 \pm 0.66^{\mathrm{a}}$ & $13.50 \pm 0.41^{\mathrm{b}}$ & $291.50 \pm 6.72^{\mathrm{a}}$ \\
\hline $\begin{array}{l}\mathrm{C}+0.33 \% \text { rocket seeds }+0.33 \% \text { carrot seeds }+0.33 \% \\
\text { bay laurel leaves }(\mathrm{D} 8)\end{array}$ & $77.80 \pm 0.61^{\mathrm{a}}$ & $12.50 \pm 0.41^{\mathrm{b}}$ & $297.00 \pm 8.00^{\mathrm{a}}$ \\
\hline
\end{tabular}

${ }^{a, b, c}$ Means within a column having different superscripts are significantly different $(\mathrm{P} \leq 0.05)$

Semen assessment pointed to a vital tool to elucidate the influences on male reproduction during summer conditions from internal and external agents. Eruca Sativa resulted in a significant augment in the concentration of sperm in the current report. This influence could be attributed to an enhancement in the synthesis of testosterone (hormone required to complete the spermatogenesis process; Walker, 2009) or to the activity of antioxidant in rocket seeds which can protect various stages of spermatozoa from apoptosis, leading to an increase in sperm production. In addition, using equal quantities of Eruca sativa, Raphanus sativus and Nigella sativa meals in place of $50 \%$ soybean protein meal, improved the semen characteristics (El-Tohamy et al., 2010). The antioxidant effects of E. Sativa can be ascribed to this improvement, which is responsible for its stress - protective effect, thus protecting sperm by numerous antioxidants, belongs to the rocket seed phytochemical component and normalizes the concentration of sperm (Gharagozloo and Aitken, 2011, Ahlbom et al., 2001). In addition, Hussein, 2013, Salem and Moustafa (2001) said that E. sativa improves healthy sperm characteristics and fertility. Ejaculate volume, percentages of motility and sperm concentration was significant $(\mathrm{P}<0.05)$ increase in the group of buck goat fed a diet containing $2 \mathrm{mg} / \mathrm{Kg}$ rocket seed oil as compared with control group (Hafez et al., 2016).

El-Nattat and El-Kady (2007) found that the total function sperm fraction, total sperm per ejaculate, and total mobile sperm of buck rabbits was augmented by supplementary black cumin, radish, and rocket meal (at a level of $50 \%$, respectively) and a mix of these meals at a level of about $17 \%$ each as a substitute for soybean meal. The improvement in the quality of semen detected herein may be associated with the existence of polyunsaturated fatty acids and various components of antioxidant in rocket seeds, carrot seeds, and bay laurel leaves. Sperms are more susceptible to be damaged through free radicals that initiate a cascade of lipid peroxidation that may harm the structure of the sperm plasma membrane (Attia et al., 2017, Castellini et al., 2003). The findings herein are in line with the results by El - Desoky et al. (2017) in the combination with dietary polyunsaturated fatty acids and antioxidants. Eruca sativa (rocket) is therefore considered to be a medicinal plant with many stated characteristic, comprising its robust erogenous influences (Font et al., 2003), the existence of alkaloids, saponins, and flavonoids in extract of rocket (Pasini et al., 2012) led to augment spermatogenesis (Homady et al., 2000), and a significant rise in activity of sperm (Barillari et al., 2005). These findings suggest that androgenic testis activity and/or vesicular gland activity in bucks receiving rocket seeds, carrot seeds or bay laurel leaves and their mixture.

The initial concentration of fructose in the sample of semen provides a decent sign of androgenic testis activity and/or vesicular gland activity (Srivastava and Pande 2017c).

\section{Effect of phytogenic feed additives on seminal plasma analysis}

Data illustrated in Table (6) showed the effects of different feed additives on seminal plasma total protein, albumin and globulin concentrations. The results indicated that seminal plasma albumin and total protein concentrations were not significantly $(\mathrm{P} \geq 0.05)$ affected by adding different levels of feed additive in comparison with the control group. While seminal plasma globulin concentration increased significantly ( $\mathrm{P}$ $\leq$ 0.05) in the group D2, D3 and D7 diet, however, bucks gave D4, D5, D6, and D8 groups showed an insignificant increase in comparison with the D1 group given feed additives free-diet. Table (6) shows the overall means of seminal plasma AST, ALT, and ALP in rabbits' bucks. Dietary supplementation significantly $(\mathrm{P} \leq 0.05)$ decreased ALP, AST, and ALT compared with the control group. The obtained 
results showed a positive correlation between decreasing AST, ALT and ALP activity of seminal plasma and with each volume of ejaculates, percentage of live cells, individual motility, and concentration (Tables 3 and 5). Seminal plasma total lipids (Table 6) significantly $(P \leq 0.05)$ decreased with diets supplemented with addition rocket seeds, carrot seeds, and bay laurel leaves and their mixture, however, $0.1 \%$ rocket seeds showed an insignificant decrease on seminal plasma total lipids as compared to the control group or the other treatment groups. Malondialdehyde concentration results presented in Table (6) indicate a significant increase $(\mathrm{P} \leq 0.05)$ in the animals fed the $\mathrm{D} 1$ diet. The groups treated with rocket seeds, carrot seeds, and bay laurel leaves showed a significant reduction $(\mathrm{P} \leq 0.05)$ in plasma MDA concentration compared to the group that fed the control diet. However, addition different plant seeds or leaves resulted in improving (TAC) as compared to the D1 group. The best TAC was recorded in the group D2, D3, D4, and D8 supplements diet followed by those groups in D5, D6, and D7.

Table (6). Effect of rocket seeds, carrot seeds, bay laurel leaves and their mixture on seminal plasma and malondialdehyde (MDA) and total antioxidant capacity (TAC) of buck rabbits.

\begin{tabular}{|c|c|c|c|c|c|c|c|c|}
\hline & D1 & $\mathrm{D} 2$ & D3 & D4 & D5 & D6 & D7 & D8 \\
\hline \multicolumn{9}{|c|}{ Seminal plasma } \\
\hline \multirow[t]{2}{*}{ Total protein (mg/dl) } & 3.58 & 4.37 & 4.20 & 3.82 & 3.87 & 3.79 & 3.99 & 3.80 \\
\hline & \pm 0.10 & \pm 0.08 & \pm 0.16 & \pm 0.05 & \pm 0.09 & \pm 0.11 & \pm 0.08 & \pm 0.13 \\
\hline \multirow[t]{2}{*}{ Albumin (mg/dl) } & 1.67 & 1.58 & 1.78 & 1.72 & 1.84 & 1.67 & 1.58 & 1.78 \\
\hline & \pm 0.04 & \pm 0.02 & \pm 0.03 & \pm 0.03 & \pm 0.04 & \pm 0.02 & \pm 0.03 & \pm 0.05 \\
\hline \multirow[t]{2}{*}{ Globulin (mg/dl) } & $1.91^{\mathrm{b}}$ & $2.79^{\mathrm{a}}$ & $2.42^{\mathrm{a}}$ & $2.10^{\mathrm{b}}$ & $2.03^{\mathrm{b}}$ & $2.12^{\mathrm{b}}$ & $2.41^{\mathrm{a}}$ & $2.02^{\mathrm{b}}$ \\
\hline & \pm 0.09 & \pm 0.09 & \pm 0.17 & \pm 0.07 & \pm 0.10 & \pm 0.09 & \pm 0.09 & \pm 0.17 \\
\hline Aspartate & $33.28^{\mathrm{a}}$ & $23.63^{\mathrm{b}}$ & $24.66^{\mathrm{b}}$ & $23.10^{\mathrm{b}}$ & $23.25^{\mathrm{b}}$ & $23.28^{\mathrm{b}}$ & $23.63^{\mathrm{b}}$ & $24.66^{\mathrm{b}}$ \\
\hline erase (IU) & \pm 1.05 & \pm 0.46 & \pm 0.41 & \pm 0.74 & \pm 0.60 & \pm 1.05 & \pm 0.49 & \pm 0.40 \\
\hline Alanine aminotransferase & $44.93^{\mathrm{a}}$ & $37.10^{\mathrm{b}}$ & $30.70^{c}$ & $31.65^{\mathrm{c}}$ & $29.81^{\mathrm{c}}$ & $34.93^{\mathrm{b}}$ & $37.10^{\mathrm{b}}$ & $30.70^{\mathrm{c}}$ \\
\hline (IU) & \pm 0.66 & \pm 1.18 & \pm 0.68 & \pm 0.97 & \pm 0.74 & \pm 0.66 & \pm 1.18 & \pm 0.68 \\
\hline \multirow[t]{2}{*}{ Alkaline phosphatase (IU) } & $13.71^{\mathrm{a}}$ & $12.41^{\mathrm{b}}$ & $12.10^{\mathrm{b}}$ & $11.96^{\mathrm{b}}$ & $12.00^{\mathrm{b}}$ & $11.51^{\mathrm{b}}$ & $12.40^{\mathrm{b}}$ & $12.30^{\mathrm{b}}$ \\
\hline & \pm 0.18 & \pm 0.27 & \pm 0.28 & \pm 0.41 & \pm 0.33 & \pm 0.18 & \pm 0.27 & \pm 0.28 \\
\hline \multirow[t]{2}{*}{ Total lipids (mg/dl) } & $239.90^{\mathrm{a}}$ & $201.10^{\mathrm{b}}$ & $218.70^{\mathrm{b}}$ & $211.70^{\mathrm{b}}$ & $216.10^{\mathrm{b}}$ & $208.90^{\mathrm{b}}$ & $206.10^{\mathrm{b}}$ & 210.70 \\
\hline & \pm 3.16 & \pm 2.96 & \pm 5.17 & \pm 4.70 & \pm 4.18 & \pm 3.14 & \pm 2.97 & ${ }^{\mathrm{b}} \pm 5.07$ \\
\hline \multirow[t]{2}{*}{ Cholesterol (mg/dl) } & $77.10^{\mathrm{a}}$ & $61.40^{\mathrm{b}}$ & $71.40^{\mathrm{b}}$ & $65.70^{\mathrm{b}}$ & $69.70^{\mathrm{b}}$ & $67.10^{\mathrm{b}}$ & $68.40^{\mathrm{b}}$ & $63.40^{\mathrm{b}}$ \\
\hline & \pm 1.13 & & \pm 1.56 & \pm 1.93 & \pm 1.68 & \pm 1.11 & \pm 1.34 & \pm 1.06 \\
\hline \multirow[t]{2}{*}{$\mathrm{MDA}(\mathrm{mmol} / \mathrm{L})$} & $1.36^{\mathrm{a}}$ & $1.05^{\mathrm{b}}$ & $1.02^{\mathrm{b}}$ & $1.06^{\mathrm{b}}$ & $1.12^{\mathrm{b}}$ & $1.15^{\mathrm{b}}$ & $1.04^{\mathrm{b}}$ & $1.06^{\mathrm{b}}$ \\
\hline & \pm 0.41 & \pm 0.32 & \pm 0.30 & \pm 0.23 & \pm 0.30 & \pm 0.47 & \pm 0.33 & \pm 0.31 \\
\hline \multirow[t]{2}{*}{$\mathrm{TAC}(\mathrm{mmol} / \mathrm{L})$} & $1.79^{\mathrm{c}}$ & $2.50^{\mathrm{a}}$ & $2.42^{\mathrm{a}}$ & $2.65^{\mathrm{a}}$ & $2.11^{\mathrm{b}}$ & $1.18^{\mathrm{b}}$ & $2.20^{\mathrm{b}}$ & $2.40^{\mathrm{a}}$ \\
\hline & \pm 0.27 & \pm 0.25 & \pm 0.30 & \pm 0.28 & \pm 0.27 & \pm 0.27 & \pm 0.25 & \pm 0.30 \\
\hline
\end{tabular}

${ }^{a, b, c}$ Means within a row having different superscripts are significantly different $(P \leq 0.05)$.

$D 1=$ Free additives supplementations (control, $C$ )., $D 2=C+1.0 \%$ rocket seeds, $D 3=C+1.0 \%$ carrot seeds, $D 4=C+$ $1.0 \%$ bay laurel leaves, $D 5=C+0.5 \%$ rocket seeds $+0.5 \%$ carrot seeds, $D 6=C+0.5 \%$ carrot seeds $+0.5 \%$ bay laurel leaves, $D 7=C+0.5 \%$ rocket seeds $+0.50 \%$ bay laurel leaves, $D 8=C+0.33 \%$ rocket seeds $+0.33 \%$ carrot seeds $+0.33 \%$ bay laurel leaves.

The protein and globulin are the part of immunity components that albumin-based antibodies are the main protein component of serum which synthesized in the hepatic tissues. The functions of albumin include regulation of the distribution of extracellular fluid, and transport agent of many substances as bilirubin, fatty acids, hormones, and vitamins (Attia et al., 2015).

Juma (2000) reported increased activity of the AST enzyme in the seminal plasma in summer. In semen, activities of transaminase (ALT and AST) are a perfect semen quality index because it assesses the stability of the sperm membrane (Umar et al., 2017, Attia and Kamel, 2012, Juyena and Stelletta, 2012). In addition, a positive correlation between sperm acrosomal damage and enzyme release was attained (Chauban et al., 1993). Additionally, high activity of seminal alkaline phosphatase in buffalo was related to depressing sperm counts, declined percentage of live cells and motility, the lowered activity of dehydrogenase also, insignificant and a tenuous reduction in the fructolytic rate (Abdou et al., 1978).

The decrease in seminal plasma total lipids correlated with decreasing level of seminal plasma cholesterol, which decreased significantly, compared with the heat stressed control through the summer 


\section{Abdel-Azeem et al.}

season. The lowest values of cholesterol and total lipids were recorded in the group of bucks fed diet containing $0.1 \%$ rocket seed.

The significant increase of MAD in the animals fed the D1 diet may indicate that rearing rabbits under hot summer condition stimulated lipid peroxidation production and deterioration of cell membrane. The endocrine and biochemical condition of male animals are also influenced by the stress of heat. Summer heat increased the level of thiobarbituric acid reactive substances, which is an oxidative marker and decreased level of glutathione peroxidase (Kowalowka et al., 2008, Nichi et al., 2006). The presence of these phytochemical compounds in rocket and carrot seeds or bay laurel leaves can facilitate animals ' ability to maintain their body homeostasis, comprising body temperature, through endogenous cell defense mechanisms to deal with heat stress-induced inflammation and oxidative stress (Attia et al., 2017, Akbarian et al., 2016). Under normal condition, the seminal fluid around the sperm comprises factors of antioxidant (such as ascorbate, glutathione, taurine, urate, $\alpha$ - tocopherol, etc.) that protect against oxidative harm (Kim and Parthasarathy, 1998). Whereas in heat stress, the seminal liquid can either lack sufficient protecting basics or the buck's body may be burdened with reactive oxygen species to devastate the normal anti-oxidant mechanisms inherent in it. In addition to leucocytes in seminal plasma, augmented levels of reactive oxygen species can be produced inside harmed or injured sperm (Tamura et al., 1988).

\section{Effect of phytogenic feed additives on blood plasma constituents}

Results showed that bucks fed rocket seeds, carrot seeds and bay laurel leaves and their mixture containing diets reduced the plasma glucose as compared to the control group Table (7). Total protein, albumin, and globulin means as affected by summer heat stress and amelioration methods are presented in Table (7). Plasma concentration of total protein from (D1-D8) ranged between $6.76 \pm 0.06-7.73 \pm 0.06 \mathrm{mg} / \mathrm{dl}$. It was obviously indicated that total protein concentration from D2-D8 groups was significantly $(\mathrm{P} \leq 0.05)$ higher than the D1 group. Regarding the present plasma albumin $(\mathrm{mg} / \mathrm{dl})$ levels in rabbit's bucks were higher $(\mathrm{P} \leq 0.05)$ in group fed diet containing different levels of rocket seeds, carrot seeds and bay laurel leaves and their mixture treated groups than that of the control group. The average plasma albumin values in these groups were ranged between $3.52 \pm 0.07-4.33 \pm 0.10 \mathrm{mg} / \mathrm{dl}$. Concerning plasma globulin (mg/dl), D3, D6, and D8 treated bucks showed higher $(\mathrm{P} \leq 0.05)$ levels compared to control and the other experimental groups. Plasma AST and ALT concentration were not significant $(\mathrm{P} \geq 0.05)$ affected by the addition of different plant seeds or leaves. It was observed that the different supplementations had no significant $(\mathrm{P} \geq 0.05)$ effect on plasma urea concentration (Table 7). Mean of blood plasma total lipids, total cholesterol, HDL, LDL and vLDL concentrations of rabbit's bucks as affected by different levels of plant seeds or leaves are illustrated in Table (7). The current results indicated that treating bucks with rocket seeds, carrot seeds, and bay laurel leaves and their mixture caused a significant $(\mathrm{P} \leq 0.05)$ reduce in total cholesterol of plasma, vLDL and LDL concentrations compared to the control. Cholesterol levels showed nearly the same trend as noticed for total lipids in all treated bucks. The reduction of cholesterol, LDL and vLDL levels ranged from (16.9 to $24.2 \%)$, (34.34 to $42.02 \%)$ and (21.05 to $39.65 \%)$ in all treated groups compared to that in control group, respectively. Plasma HDL level was not significantly affected by supplementing different levels of rocket seeds, carrot seeds, and bay laurel leaves and their mixture. On the other hand, blood plasma levels of triglycerides concentrations decreased significantly $(\mathrm{P} \leq 0.05)$ in bucks treated with $0.1 \%$ rocket seeds, $0.1 \%$ carrot seeds and $0.1 \%$ bay laurel leaves in comparison with the control group. There were significant differences between individual feed additives and their mixture groups. In addition, mixtures of rocket seeds, carrot seeds, and bay laurel leaves was more effective than that on rocket seeds, carrot seeds and bay laurel leaves as a sole feed additive on this trait. Table (7) presents the effects of various levels of natural plant seeds and bay laurel leaves on rabbit blood antioxidant constituents. A significant, triple mixture-dependent (rocket seeds, carrot seeds, and bay laurel leaves) decrease $(\mathrm{p} \leq 0.05)$ plasma MDA compared to other groups.

Al-Daraji and Razuki (2012) reported that supplementation of the roosters ration with rocket salad seeds resulted in significant decrease concentrations of glucose in blood plasma during most months of the experimental diets when compared with the control group.

The higher values of plasma proteins as affected by administration of different medicinal plants may reflect the improvement in digestibility and metabolism as previously referred (Attia et al., 2015, Saleh, 2005). 
Table (7). Effect of rocket seeds, carrot seeds, bay laurel leaves and their mixture on blood plasma biochemical components and plasma total antioxidant capacity (TAC) and malondialdehyde (MDA) of buck rabbits.

\begin{tabular}{|c|c|c|c|c|c|c|c|c|}
\hline & D1 & D2 & D3 & D4 & D5 & D6 & D7 & D8 \\
\hline \multicolumn{9}{|l|}{ Blood plasma } \\
\hline \multirow{2}{*}{ Glucose (mg/dl) } & $110.00^{\mathrm{a}}$ & $92.50^{\mathrm{b}}$ & $93.90^{\mathrm{b}}$ & $95.50^{\mathrm{b}}$ & $93.60^{\mathrm{b}}$ & $92.10^{\mathrm{b}}$ & $91.80^{\mathrm{b}}$ & $91.90^{\mathrm{b}}$ \\
\hline & \pm 2.44 & \pm 1.78 & \pm 1.14 & \pm 0.88 & \pm 1.34 & \pm 2.44 & \pm 1.78 & \pm 1.14 \\
\hline \multirow[t]{2}{*}{ Total protein $(\mathrm{mg} / \mathrm{dl})$} & $6.76^{\mathrm{b}}$ & $7.14^{\mathrm{a}}$ & $7.70^{\mathrm{a}}$ & $7.52^{\mathrm{a}}$ & $7.26^{\mathrm{a}}$ & $7.73^{\mathrm{a}}$ & $7.15^{\mathrm{a}}$ & $7.71^{\mathrm{a}}$ \\
\hline & \pm 0.06 & \pm 0.10 & \pm 0.11 & \pm 0.15 & \pm 0.06 & \pm 0.06 & \pm 0.10 & \pm 0.11 \\
\hline \multirow{2}{*}{ Albumin (mg/dl) } & $3.52^{\mathrm{b}}$ & $4.14^{\mathrm{a}}$ & $4.33^{\mathrm{a}}$ & $4.25^{\mathrm{a}}$ & $4.09^{\mathrm{a}}$ & $4.31^{\mathrm{a}}$ & & $4.05^{\mathrm{a}}$ \\
\hline & \pm 0.07 & \pm 0.11 & \pm 0.10 & \pm 0.15 & \pm 0.13 & \pm 0.05 & ( & \pm 0.14 \\
\hline \multirow[t]{2}{*}{ Globulin (mg/dl) } & $3.24^{\mathrm{b}}$ & $3.00^{\mathrm{b}}$ & $3.47^{\mathrm{a}}$ & $3.27^{\mathrm{b}}$ & $3.07^{\mathrm{b}}$ & $3.42^{\mathrm{a}}$ & $3.01^{\mathrm{b}}$ & $3.66^{\mathrm{a}}$ \\
\hline & \pm 0.06 & \pm 0.10 & \pm 0.14 & \pm 0.16 & \pm 0.10 & \pm 0.06 & \pm 0.10 & \pm 0.14 \\
\hline \multirow[t]{2}{*}{ AST (IU) } & 56.50 & 54.20 & 55.70 & 55.60 & 54.00 & 56.50 & 57.20 & 56.70 \\
\hline & \pm 0.46 & \pm 0.35 & \pm 0.36 & \pm 0.33 & \pm 0.38 & \pm 0.40 & \pm 0.35 & \pm 0.35 \\
\hline \multirow[t]{2}{*}{ ALT (IU) } & 30.20 & 31.20 & 29.30 & 28.90 & 30.50 & 30.70 & 32.20 & 34.30 \\
\hline & \pm 0.21 & \pm 0.20 & \pm 0.30 & \pm 0.28 & \pm 0.29 & \pm 0.31 & \pm 0.32 & \pm 0.30 \\
\hline \multirow[t]{2}{*}{ Urea (mg/dl) } & 40.34 & 38.65 & 37.89 & 37.79 & 40.33 & 41.37 & 36.65 & 37.86 \\
\hline & \pm 0.28 & \pm 0.51 & \pm 1.03 & \pm 0.71 & \pm 0.52 & \pm 0.38 & \pm 0.50 & \pm 1.03 \\
\hline \multirow[t]{2}{*}{ Cholesterol (mg/dl) } & $127.74^{\mathrm{a}}$ & $\begin{array}{l}111.62 \\
b\end{array}$ & 104.66 & ${ }_{b}^{109.96}$ & ${ }_{b}^{104.22}$ & $\underset{b}{101.14}$ & $\begin{array}{l}101.78 \\
b\end{array}$ & $105.28^{\mathrm{b}}$ \\
\hline & \pm 2.61 & \pm 4.03 & \pm 4.31 & \pm 2.70 & \pm 2.39 & \pm 2.61 & \pm 4.13 & \pm 3.34 \\
\hline \multirow[t]{2}{*}{$\mathrm{HDL}(\mathrm{mg} / \mathrm{dl})$} & 62.00 & 68.50 & 59.90 & 63.00 & 60.20 & 55.00 & 56.50 & 62.90 \\
\hline & \pm 2.08 & \pm 2.86 & \pm 2.46 & \pm 2.21 & \pm 1.99 & \pm 2.09 & \pm 2.85 & \pm 2.47 \\
\hline \multirow[t]{2}{*}{ LDL (mg/dl) } & $49.50^{\mathrm{a}}$ & $28.70^{\mathrm{c}}$ & $30.30^{\mathrm{b}}$ & $31.30^{\mathrm{b}}$ & $30.80^{\mathrm{b}}$ & $32.50^{\mathrm{b}}$ & $31.70^{\mathrm{b}}$ & $29.00^{\mathrm{b}}$ \\
\hline & \pm 0.77 & \pm 1.09 & \pm 1.03 & \pm 0.81 & \pm 0.98 & \pm 0.77 & \pm 1.09 & \pm 1.03 \\
\hline \multirow[t]{2}{*}{$\operatorname{vLDL}(\mathrm{mg} / \mathrm{dl})$} & $16.24^{\mathrm{a}}$ & $14.42^{\mathrm{b}}$ & $14.46^{\mathrm{b}}$ & $15.66^{\mathrm{ab}}$ & $13.22^{\mathrm{c}}$ & $\begin{array}{l}13.64^{\mathrm{c}} \\
+\end{array}$ & $13.58^{c}$ & $13.38^{\mathrm{c}}$ \\
\hline & \pm 0.02 & \pm 0.10 & \pm 0.10 & \pm 0.09 & \pm 0.07 & $\begin{array}{l} \pm \\
0.02\end{array}$ & \pm 0.10 & \pm 0.10 \\
\hline \multirow[t]{2}{*}{ Triglyceride (mg/dl) } & $81.20^{\mathrm{a}}$ & $72.10^{\mathrm{b}}$ & $72.30^{\mathrm{b}}$ & $78.30^{\mathrm{ab}}$ & $66.10^{c}$ & $68.20^{\mathrm{c}}$ & $67.90^{c}$ & $66.80^{\mathrm{c}}$ \\
\hline & \pm 1.12 & \pm 0.94 & \pm 2.34 & \pm 1.15 & \pm 1.12 & \pm 1.10 & \pm 0.91 & \pm 2.24 \\
\hline \multirow[t]{2}{*}{ Total Lipid (mg/dl) } & $405.90^{\mathrm{a}}$ & 321.10 & $\begin{array}{l}318.30 \\
b\end{array}$ & $\begin{array}{l}301.80 \\
b\end{array}$ & $\begin{array}{l}302.50 \\
b\end{array}$ & $\begin{array}{l}304.90 \\
b\end{array}$ & 321.30 & $328.20^{\mathrm{b}}$ \\
\hline & & \pm 13.61 & \pm 13.12 & \pm 12.79 & \pm 11.51 & \pm 4.33 & \pm 13.62 & \pm 12.15 \\
\hline \multirow[t]{2}{*}{ TAC (mmol/L) } & $0.72^{\mathrm{d}} \pm 0.0$ & $1.42^{\mathrm{b}}$ & $1.43^{\mathrm{b}}$ & $1.45^{\mathrm{b}}$ & $1.10^{\mathrm{c}}$ & $1.11^{\mathrm{c}}$ & $1.12^{\mathrm{c}}$ & $1.64^{\mathrm{a}}$ \\
\hline & 2 & \pm 0.07 & \pm 0.10 & \pm 0.10 & \pm 0.10 & \pm 0.04 & \pm 0.08 & \pm 0.10 \\
\hline \multirow[t]{2}{*}{ MDA (mmol/L) } & $1.49^{\mathrm{a}}$ & $1.00^{\mathrm{b}}$ & $1.00^{\mathrm{b}}$ & $1.06^{\mathrm{b}}$ & $0.88^{\mathrm{c}}$ & $0.84^{\mathrm{c}}$ & $0.80^{\mathrm{c}}$ & $0.60^{\mathrm{d}}$ \\
\hline & \pm 0.04 & \pm 0.06 & \pm 0.05 & \pm 0.05 & \pm 0.05 & \pm 0.03 & \pm 0.07 & \pm 0.04 \\
\hline
\end{tabular}

${ }_{a, b, c, d}$ Means within a row having different superscripts are significantly different $(P \leq 0.05)$

$D 1=$ Free additives supplementations $($ control, $C) ., D 2=+1.0 \%$ rocket seeds, $D 3=C+1.0 \%$ carrot seeds, $D 4=C+$ $1.0 \%$ bay laurel leaves, $D 5=+0.5 \%$ rocket seeds $+0.5 \%$ carrot seeds, $D 6=C+0.5 \%$ carrot seeds $+0.5 \%$ bay laurel leaves, $D 7=C+0.5 \%$ rocket seeds $+0.50 \%$ bay laurel leaves, $D 8=C+0.33 \%$ rocket seeds $+0.33 \%$ carrot seeds $+0.33 \%$ bay laurel leaves, $A S T=$ Aspartate aminotransferase, $A L T=$ Alanine aminotransferase, $H D L=H i g h$ density lipoproteins, $L D L=L o w$ density lipoproteins, $v L D L=$ Very low density lipoproteins.

The extract and volatile oil of Eruca sativa seeds work as diuretics and significantly augmented $\mathrm{Cl}-, \mathrm{Na}+$, and K+, extraction in animal urine (Mahran et al., 1992). Nevertheless, Eruca sativa seeds are utilized as an antimicrobial, lactagogue, and a diuretic to break the calculi of the renal system and to stimulate vomiting (Boulos, 1983).

The decrease in total cholesterol of plasma $(p \leq 0.05)$ may be due to the highest binding capacity of natural plant seeds and leaves against glycodeoxycholic acid. It is slightly bound to taurocholic acid and taurodeoxycholic acid, which indicates that plant seeds and leaves may raise the excretion of fecal bile acid, resulting in lower cholesterol levels of plasma compared to control groups (Adisakwattana et al. 2010). In addition, Casamassima et al. (2016) showed that rabbits fed a diet containing one gram of dried bay leaves (Laurus nobilis) per one kilogram feed resulted in a significantly increased HDL cholesterol levels and reduction in AST and ALT levels, triglycerides, glucose, LDL cholesterol, and total cholesterol. The 


\section{Abdel-Azeem et al.}

capacity of total antioxidant may be a show for the accessibility of reduction factors in plasma, and therefore plasma's ability to clean free radicals created from processes of oxidation (Kambayashi et al., 2009). So, the opposite influence was observed in regard to TAC, where the values were significantly ( $\mathrm{p} \leq$ 0.05) augmented with an addition of additive-containing three types of plant products. These results were connected with Basyony and Azoz (2017) who reported that dietary supplementation of rocket (Eruca Sativa) seeds, carrot (Daucus Carota L) seeds or bay laurel leaves (Bay laurel Nobilis L), and their mixture improved significantly the antioxidant status of doe rabbits and their offspring's, during the pregnancy and lactation periods. In addition, Casamassima, et al. (2017) stated that serum levels of MDA were reduced in rabbits received a diet containing one g per $\mathrm{kg}$ of dried bay leaves (Laurus nobilis) in feed besides $2.5 \%$ pig fat than in rabbits fed $2.5 \%$ pig fat alone. This improvement tends to that phytogenic compound with antioxidant, antibacterial and anti-inflammatory properties (Attia et al., 2017).

\section{CONCLUSIONS}

It is well demonstrated that the supplementation of rocket seeds, carrot seeds, bay laurel leaves, and their mixtures during the Egyptian summer season has positive effects on buck semen quality. In addition, it had a beneficial effect on blood lipid regulation which was demonstrated to be ascribed to their antioxidant activity and on lipid peroxide and the anti-oxidative status of rabbit reared under summer conditions. The phytochemical compounds in rocket and carrot seeds or bay laurel leaves can facilitate animals' ability to maintain their body homeostasis, comprising body temperature, through endogenous cell defense mechanisms to deal with heat stress-induced inflammation and oxidative stress.

\section{REFERENCES}

Abdo Z.M.A. 2003. Using Egyptian Eruca-Sativa meal in broiler ration with or without microbial phytase. Egypt. J. Nutrition. Feeds, 6: 97-114.

Abdou M. S. S., El-Guindi M. M., El-Menoufy A. A., and Zaki, K. 1978. Enzymic Profile of the Semen of Bovines (Bubalus bubalis and Bos taurus). Zentralblatt für Veterinärmedizin Reihe A, 25: 222-230.

Adisakwattana S., Moonrat J., Srichairat S.m Chanasit C., Tirapongporn H., Chanathong B., Ngamukote S., Mäkynen K., and Sapwarobol S. 2010. Lipid-lowering mechanisms of grape seed extract (Vitis vinifera L.) and its antihyperlidemic activity. J Med Plants Res. 4:2113-2120.

Ahlbom, E, Prins, GS, and Ceccatelli, S. 2001. Testosterone protects cerebellar granule cells from oxidative stress induced cell death through a receptor mediated mechanism. Brain Res. 892: 255-262.

Akbarian, A., Michiels, J., Degroote, J., Majdeddin, M., Golian, A., and De Smet, S. 2016. Association between heat stress and oxidative stress in poultry; mitochondrial dysfunction and dietary interventions with phytochemicals. J. Anim. Sci. Biotech. 7: 37-51.

Al-Daraji, H. J., and Razuki R. H. 2012. Effect of dietary supplementation with different levels of rocket salad (Eruca sativa) seeds powder on blood plasma traits of White Hy - line laying breeder roosters. Kufa J. Agric. Sci. 4(1): 31-42. (In Arabic)

Armstrong, W. D. and Carr, C. W. 1964. Physiological Chemistry Laboratory Direction, $3^{\text {rd }}$ Ed. Burges Publishing, Minneololis, MN, USA.

Attia, Y. A. and Kamel, K. I. (2012). Semen quality, testosterone, seminal plasma biochemical and antioxidant profiles of rabbit bucks fed diets supplemented with different concentrations of soybean lecithin. Anim. 6 (5): 824-833.

Attia, Y. A., Hamed, R. S., F. Bovera, A. E. Abd El-Hamid, M. A. Al-Harthi, H. A. and Shahba, (2017). Semen quality, antioxidant status and reproductive performance of rabbits bucks fed milk thistle seeds and rosemary leaves. Animal Rep. Sci., 184(Sep.):178-186. 
Attia, Y.A., Bovera, F., El-Tahawy, W.S., El-Hanoun, A.M., Al-Harthi, M.A. and Habiba, H. I. (2015). Productive and reproductive performance of rabbits does as affected by bee pollen and/or propolis, inulin and/or mannan-oligosaccharides. World Rabbit Sci., 23(4): 273-282.

Barillari J., Canistro, D., Paolini M., Ferroni F., Pedulli G.F., Iori, R., and Valgimigli L. 2005. Direct antioxidant activity of purified glucoerucin, the dietary secondary metabolite contained in rocket (Eruca sativa Mill.) seeds and sprouts. J. Agric. Food Chem. 53: 2475-2482.

Basyony M.M., and Azoz, A. A. 2017. Influence of using natural feed additives on some reproductive and productive performance of doe rabbits. Egyptian J. Rabbit Sci. 27 (2): 463 - 484.

Bogin E., and Keller P. 1987. Application of clinical biochemistry-try to medically relevant animal models and standardization and quality control in animal biochemistry. J. Clin. Chem. Biochem. 25: 873-878.

Boulos I. 1983. Medical plants of North Africa reference publication. Inc. Proc., $2^{\text {nd }}$ Conference Faculty of Veterinary Medicine, Cairo University, Cairo, Egypt.

Bradley, P. R. 1992. British Herbal Compendium, 1, 395-399. Boumemouth: British Herbal Medicine Association.

Burstein M., Scholnick H. R., and Morfin R. 1970. Rapid method for the isolation of lipoproteins from human plasma by precipitation with polyanions. J. Lipid. Res. 11:583-595.

Casamassima D., Chiosi F., Vizzarri F., Palazzo M., and Costagliola C. 2017. The effect of Laurus nobilis on the blood and lenses antioxidant activity in rabbit under fat-enriched diet. Physiol. Res. 66: 325-333.

Casamassima D., Palazzo M., Vizzarri F., Coppola R., Costagliola C., Corino C., and Di Costanzo A. 2016. Dietary effect of dried bay leaves (Laurus nobilis) meal on some biochemical parameters and on plasma oxidative status in New Zealand white growing rabbit. J. Anim. Physiol. Anim. Nutr. 101: 175-184.

Castellini C., Lattaioli P., Dal Bosco, A., Minelli A., and Mugnai C. 2003. Oxidative status and semen characteristics of rabbit buck as affected by dietary vitamin E, C and n-3 fatty acids. Reprod. Nutr. Dev., 43: 91-103.

Chauban M.S., Kapila R., Gandhi K. K., and Anandm S. R. 1993. Acrosome damage and enzyme leakage of goat spermatozoa during dilution, cooling and freezing. Andrologia, 26: 21-26.

Cheeke P. R. 1986. Potential of rabbit production in tropical and subtropical agricultural Systems. J. Anim. Sci. 63: 1581-1586.

Ching L.S., and Mohamed S. 2001. Alpha-Tocopherol Content of 62 Edible Tropical Plants. J. Agric. Food Chem. 49: 3101-3105.

Da Silva Dias J.C. 2014. Nutritional and health benefits of carrots and their seed extracts. Food Nutri. Sci. 5: 2147-2156.

Dias M.I., Barros L., Dueñas M., Alves R.C., Oliveira M.B., Santos-Buelga C., and Ferreira I.C. 2014. Nutritional and antioxidant contributions of Laurus nobilis L. leaves: Would be more suitable a wild or a cultivated sample? Food Chem. 156: 339-346.

Doumas B.T., Waston W., and Biggs H. H. 1977. Albumin standards and the measurements of plasma albumin with bromocresol green. Clin. Chem. Acta 31: 87-96.

Duncan D B. 1955. Multiple range and F. test. Biometric. 11:42.

Eisenberg D.M.R., Kessler C., Foster C., Norlock F.E., Calkins D.R., and Delbanco T.L. 1993. Unconventional medicine in the United States. Preference, Cost and patterns of use. N Engl J Med. 328: 246-252.

El-Desoky N. I., Hashem N. M., Elkomy, A., and Abo-elezz, Z. R. 2017. Physiological response and semen quality of rabbit bucks supplemented with Moringa leaves ethanolic extract during summer season. Anim. 11 (9): 1549-1557.

Elnagar, S. A. 2010. Royal jelly counteracts bucks" summer infertility". Anim. Rep. sci., 121: 174-180. 


\section{Abdel-Azeem et al.}

El-Nattat, W.S., and El-Kady, R.I. 2007. Effect of Different Medicinal Plant Seeds Residues on the Nutritional and Reproductive Performance of Adult Male Rabbits. Int. J. Agri. Biol. 9(3)2: 479-485.

El-Nomeary S. A. A., El- Kady R. I., El-Shahat A. A., and El-Nattat W.S. 2016. Prolonged effect of some plant seeds meals supplementation on the performance and plasma parameters in male rabbits. Int. J. Chem. Tech. Res. 9(12): 68-80.

El-Tohamy M. M., El-Nattat W. S., and El-Kady R. I. 2010. The beneficial effects of Nigella sativa, Raphanus sativus and Eruca sativa seed cakes to improve male rabbit fertility, immunity and production. J. Amer. Sci. 6(10): 1247-1255.

Fawcett, J.K. and Scott, J.E. (1960). A Rapid and Precise Method for the Determination of Urea. J. Clin. Path., 13, 156-159.

Font, R., Galan, S., Ruiz, P., Villatoro, P. and Delrio C. 2003. Characterization of the sensorial, morphological and agronomic attributes of a world collection of rocket. Brassica, $5^{\text {th }}$ international symposium on brassica and the $16^{\text {th }}$ crucifer genetic work shop.

Fringes C. S., Fendly T. W., Rum, R. T., and Queen C. A. 1972. Improved determination of total plasma lipids by the soulfo-phospho-vanilin reaction. Clinica chimica, 18: 673-674.

Gharagozloo P., and Aitken R.J. 2011. The role of sperm oxidative stress in male infertility and the significance of oral antioxidant therapy. Hum. Reprod. 26: 1628-1640.

Hafez Y. H., El-Badawy M. M., Youssef H.F.H., El-Maghraby M. M., El-Sanafawy H. A., and El-Giziry A. A. 2016. Effect of Rocket Oil Addition on Preductive and Reproductive Performance and Some Blood Parameters of Zaraibi Goats. J. Anim. Poult. Prod., Mansoura Univ.7 (9): 339 - 345.

Homady M.H., Hussain H.H., Tarawaneh K.A., Shakhanbeh J.M., and Al-Rheail I.A. 2000. Effects of oral application of some medicinal plant extracts used in Jordan on social aggression as well as testicular and preputial gland structure in male mice. Pak. J. Biol. Sci. 3: 389-402.

Horbowicz M., Kosson R., Grzesiuk A., and Bski H.D. 2008. Anthocyanins of Fruits and Vegetables-Their Occurrence Analysis and Role in Human Nutrition. Veg. Crops Res. Bull. 68: 5-22.

Hussein, Z.F. 2013. Study the effect of Eruca sativa leaves extract on male fertility in albino mice. J. AlNahrain Univ. 16(1): 143-146.

Ibrahim, S.A.M. 2005. Effect of some medicinal plants as feed additives on growth and some metabolic changes in rabbits. Egypt J. Nutr. Feeds, 8: 207-219.

IRRG, International Rabbit Reproduction Group.2005. Guidelines for the handling of rabbit bucks and semen. World Rabbit Sci., 13: 71- 91.

Johnson, A. M., Rohlfs, E. M. and Silverman, L. M. 1999. Proteins. In: Burtis C.A. \& Ashwood E.R. (eds). Tietz textbook of clinical chemistry, $3^{\text {rd }}$ Ed., W.B. Saunders Company, Philadephia. 477-540.

Juma, F.T. 2000. A Study the Effect of Seasonal Changes on Physical and Biochemical Properties of Friesian Bull Semen in the Middle Part of Iraq. Ph.D. Thesis Veterinary Medicine College Baghdad University.

Juyena N.S., and Stelletta C. 2012. Seminal Plasma: An Essential Attribute to Spermatozoa. J. Androl. 33(4):536-550.

Kambayashi Y., Binh N.T., Asakura H.W., Hibino Y., Hitomi Y., Nakamura H., and Ogino K. 2009. Efficient assay for total antioxidant capacity in human plasma using a 96-well microplate. J. Clin. Biochem. Nutri. 44: 46-51.

Kim J.G., and Parthasarathy S. 1998. Oxidation and the spermatozoa. Seminars Reprod. Endocrinol. 16: 235-239.

Kim S.J., Jin S., and Ishii G. 2004. Isolation and structural elucidation of 4-(B-d-glucopyranosyldisulfanyl) butyl glucosinolate from leaves of rocket salad (Eruca sativa L.) and its antioxidative activity. Biosci. Biotechnol. 68, 2444-2450.

Koracevic D., Koracevic G., Djordjevicm V., Andrejevic S., and Cosic V. 2001. Method for the measurement of antioxidant activity in human fluids. J Clin. Pathol., 54: 356-36. 
Kowalowka M., Wysocki P., Fraser L., and Strzezek J. 2008. Extracellular superoxide dismutase of boar seminal plasma. Reprod Domest Anim. 43:490-496.

Lebas F. 2004. Reflections on rabbit nutrition with a special emphasis on feed ingredients utilization. In Proc: the $8^{\text {th }}$ World Rabbit Congress, 7-10 September, 2004. Puebla, Mexico. 686-736.

Lee, C. Y. 2002. Explaining just how vitamin C works against cancer. Lancet. 359:9301-9305.

Leung A.Y., and Foster S. 1996. Drugs and Cosmetics, Encyclopedia of common natural ingredients used in food. $2^{\text {nd }} . J o h n$ Wiley and Sons, Inc. New York, USA.

LPHSI, 1990. Livestock and Poultry Heat Stress Indices, Agriculture Engineering Technology Guide, Clemson University, Sc 29634, USA.

Mahran G.H., Kadry H.A., Thabet C.K., El-Olemy, M.M., Al-Azizi M.M., Schiff P.L., and Wong, L.K. 1992. Gc/MS analysis of volatile oil from Eruca sativa seeds. Int. J. Pharmacol., 30: 135-7.

Mahrose Kh.M., Abd El-Monem, U.M., and Peris, S.I. 2010. Effects of photoperiod and mating or semen collection times on the performance of does and bucks of New Zealand white rabbits under hot climatic conditions of Egypt. In Proc: $6^{\text {th }}$ Inter. Conf. Rabbit Prod. Hot Clim., 1-4 February 2010. Assuit, Egypt. 503-520.

Muralidharan P., Balamurugan G., and Kumar P. 2008. Inotropic and Cardioprotective Effects of Daucus carota Linn. On Isoproterenol- Induced Myocardial Infarction. Bangladesh J. Pharmacol 3: 74-79.

Nichi M., Bols P.E., Zuge R.M., Barnabe V.H., Goovaerts I.G., Barnabe R.C., and Cortada, C.N. 2006. Seasonal variation in semen quality in Bos indicus and Bos taurus bulls raised under tropical conditions. Theriogenology. 66:822-828.

Ondruska L., Rafay J., Okab A.B., Ayoub M.A., Al-Haidary A.A. Samara E.M., Parkanyi, V., Chrastinova L., Jurcik R., and Massanyi P. 2011. Influence of elevated ambient temperature upon some physiological measurements of New Zealand White rabbits. Vet Med-Czech. 56:180-186.

Pasini F., Verardo V., Caboni, M.F., and D'Antuono L.F. 2012. Determination of glucosinolate and phenolic compounds in rocket salad by HPLC-DAD-MS: Evaluation of Eruca sativa Mill. and Diplotaxis tenuifolia L. genetic resources. Food Chem. 133: 1025-1033.

Perumal P., Srivastava N., Pande M. and Ghosh, S.K. 2017. Counting Sperm Numbers. In: Srivastava N, and Pande M. (eds). Protocols in Semen Biology (Comparing Assays). Springer Nature Singapore Pte Ltd, Singapore, 73-87.

Reitman S., and Frankel S. 1975. Colorimetric determination of GOT- Gamma GPT. Amer. J. Clin. Pathol; 28:56.

Sabin K., Sahin N., Onderci M., Yarahoglu S., and Kucuk O. 2001. Protective role of supplemental vitamin $\mathrm{E}$ on lipid peroxidation, vitamins $\mathrm{E}, \mathrm{A}$ and some mineral concentrations of broilers reared under heat stress. Vet. Med. Czech, 46: 140-144.

Saleh, A. A. 2003. Using some salts to alleviate heat stress and improve physiological responses in sheep under hot conditions in Egypt. Thesis . M.Sc. Fac. Agric., Al-Minia Univ., Cairo, Egypt.

Salem M.A.R., and Moustafa N. A. 2001. Histological and quantitative study of the effect of Eruca sativa seed oil on the testis of albino rat. Egypt. J. Hosp. Med. 2: 148-162.

SAS. 2000. SAS/STAT User's Guide (Version 8.1). SAS Inst. Inc., Cary NC, USA

Singh K., Dhongade H., Sing N., and Kashyap P. 2010. Hypolipidemic Activity of Ethanolic Extract of Daucus carota Seeds in Normal Rats. Int. J.Biomed. Adva. Res.., 1, 73-80.

Srivastava N. and Pande M. 2017a. Estimates of Sperm Motility. In: Srivastava N. and Pande M. (ed). Protocols in Semen Biology (Comparing Assays). Springer Nature Singapore Pte Ltd, Singapore, 43-55.

Srivastava N. and Pande M. 2017b. Biochemical Assays in Spermatology. In: Srivastava N. and Pande M. (ed). Protocols in Semen Biology (Comparing Assays). Springer Nature Singapore Pte Ltd, Singapore, 109-122. 


\section{Abdel-Azeem et al.}

Srivastava, N. and Pande, M. 2017c. Estimating Metabolic Activity of Spermatozoa. In: Srivastava, N. \& Pande, M. (ed). Protocols in Semen Biology (Comparing Assays). Springer Nature Singapore Pte Ltd, Singapore, 123-144.

Srivastava, N., Pande, M. and Din, O. 2017. Evaluating Sperm Cell Morphology In: Srivastava N. and Pande M. (ed). Protocols in Semen Biology (Comparing Assays). Springer Nature Singapore Pte Ltd, Singapore, 89-107

Talalay P., Fahey, and J.W. 2001. Phytochemicals from crucierous plants protect against cancer by modulating carcinogen metabolism. J. Nutrition., 131, 3027-3033.

Tamura M., Tamura T., Tyagi S.R., and Lambeth, J.D. 1988.The superoxide-generating respiratory burst oxidase of human neutrophil plasma membrane: Phosphatidylserine as an effectors of the activated enzyme. J Biol. Chem., 263: 17621-17626.

Umar, S., Ahmad, M., Ahmad, I., Zubair, M., Umar, Z., Qureshi, A.S., Manzoor, A., Murtaza, A. and Shaukat, A. 2017. Correlation of biochemical constituents of seminal plasma with semen quality in Teddy goat (Capra hircus) bucks. Andrologia. 1-7.

Walker, W.H. 2009. Molecular mechanisms of testosterone action in spermatogenesis. Steroids 74, $602-607$.

Wieland H., and Seidel D. 1983. A simple specific method for precipitation of low density lipoproteins. J Lipid Res. 24(7): 904-909.

علف نباتية خلال موسيولوجية، وجودة الصيف في مصر المنوي ومقاييس الام البيوكيميائية في ذكور الأرانب المدعمة بإضافات

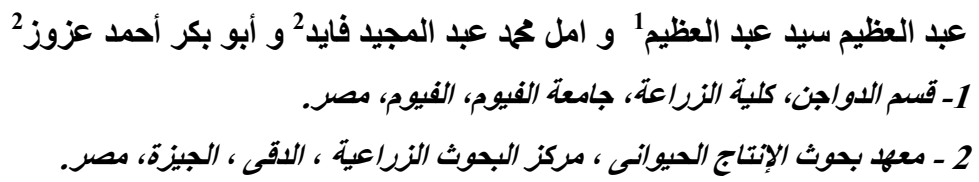

تم تقسيم اثثان وسبعون ذكر أر انب نيوزيلندي الأبيض الناضج (NZW) بشكل عثو ائي إلى ثماني مجمو عات بكل منها تسعة ذكور لتقبييم

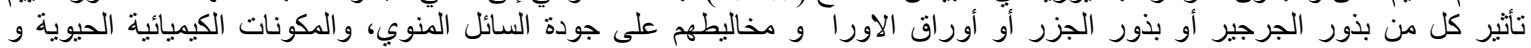

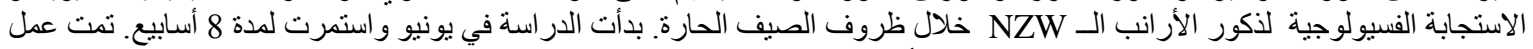

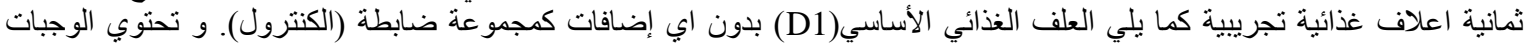

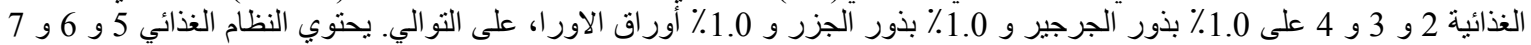

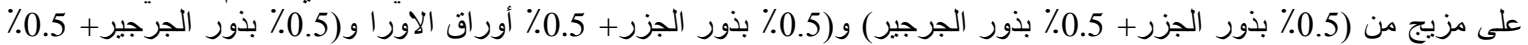

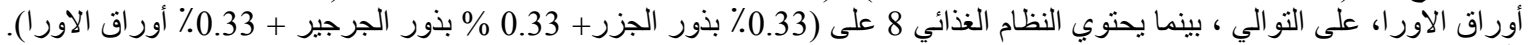

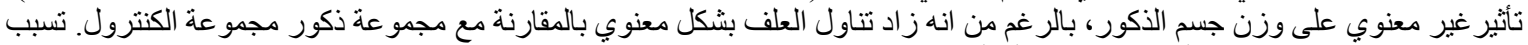

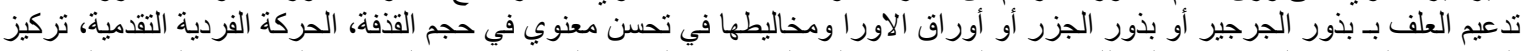

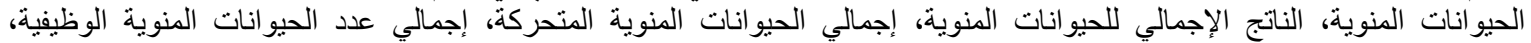

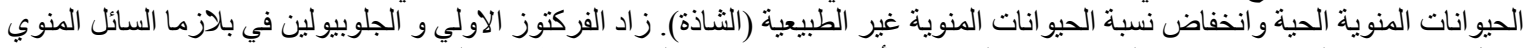

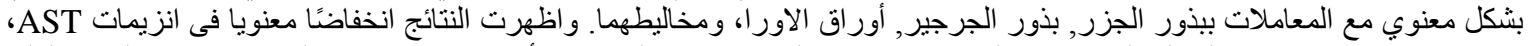

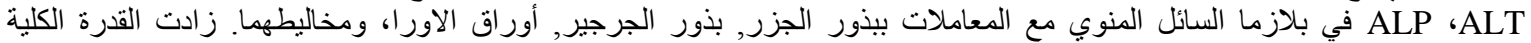

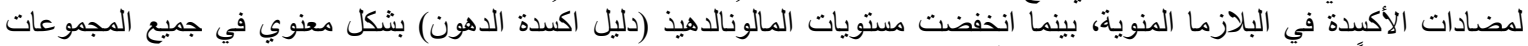

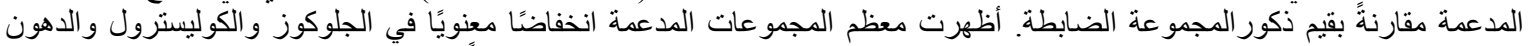

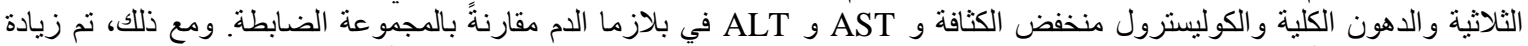

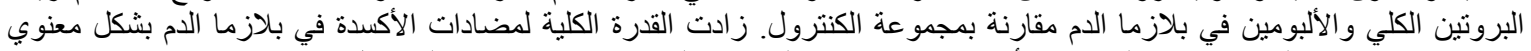

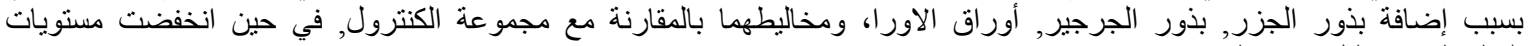
المالونالدهيد (دليل اكسدة الدهون). 